\title{
A ordem de um tempo: folhetos na coleção Barbosa Machado
}

\author{
Rodrigo Bentes Monteiro \\ Ana P. Sampaio Caldeira
}

La biblioteca es ilimitada y periódica. Si un eterno viajero la atravesara en cualquier dirección, comprobaría al cabo de los siglos que los mismos volúmenes se repiten en el mismo desorden. Mi soledad se alegra con esa elegante esperanza.

Jorge Luis Borges

Este artigo refere-se à história de uma grande coleção, formada aproximadamente por 4.300 obras em 5.700 volumes. ${ }^{1}$ Uma compilação que contém álbuns de retratos em estampas, opúsculos, mapas e obras avulsas, agrupados por zelo e diligência de Diogo Barbosa Machado (1682-1772), abade de Santo Adriāo de Sever. Como se sabe, este conjunto documental foi doado à Real Biblioteca entre 1770 e 1773, após o grande terremoto de 1755 que acometeu Lisboa, praticamente destruindo aquele acervo original. Em 1810, a Livraria Barbosa Machado viajou para o Rio de Janeiro com a vinda da Corte régia para esta cidade, no segundo lote, aos cuidados do bibliotecário Luís Marrocos. Depois dos acordos que sucederam a independência do Brasil, faria parte da Biblioteca Imperial, mais tarde Biblioteca Nacional.

Pretende-se enfatizar o estudo da taxionomia empreendida pelo colecionador em relação aos opúsculos, destacando as principais questôes que norteiam a abordagem deste corpo de documentos. São mais de três mil folhetos entre muitos impressos e alguns manuscritos, produzidos entre os séculos XVI e XVIII, agrupados em 145 volumes existentes na seção de obras raras da Biblioteca Nacional do Brasil. Por isso abordamos também neste artigo os vários tempos percorridos por esta documentação, em suas várias concepções de história: o período de publicação dos folhetos, a clas- 
sificação operada pelo colecionador, o tratamento posterior da coleção pelos bibliotecários. $^{2}$

\section{Uma civilização da escrita}

Mas antes é preciso destacar o valor e a peculiaridade dessas pequenas obras. Blandine Kriegel observa a importância da palavra escrita nas sociedades modernas: enquanto monumentos e medalhas - vestígios deixados pelas civilizações do passado - eram estudados pela arqueologia e pela numismática, as atas escritas, sobretudo jurídicas, eram consideradas produçōes "naturais" das novas sociedades. Para o estudo e o reconhecimento da validade desses documentos, desenvolveu-se nos séculos XVI e XVII uma erudição metódica e a técnica de autenticação documental conhecida como diplomática, que embora não diminuísse a importância da história dos povos antigos, abria espaço para novas sociedades a partir do estudo de fontes escritas. ${ }^{3}$

A autenticação e a prática de colecionar esse tipo de material traziam subjacente, como lembra Íris Kantor, uma questão política na ordem do dia para os Estados modernos. Na conjuntura posterior ao fim da Guerra dos Trinta Anos, em 1648, a concorrência entre potências européias levava Portugal a munir-se com documentação comprobatória, investindo na política de construção da memória histórica de seus domínios. Mediante documentos escritos, configurava-se um novo discurso - mais secular - de justificação do império luso. ${ }^{4}$

Valoriza-se aqui o papel da palavra escrita na livraria de Diogo Barbosa Machado. Diferente de compilações do período voltadas para medalhas, moedas e outros vestígios materiais do passado, este conjunto tem como ponto central esses documentos. ${ }^{5}$ Os folhetos presentes na coleção Barbosa Machado são expressões de uma civilização da escrita, segundo Fernando Bouza Álvarez. Para este historiador, os manuscritos, impressos e retratos seriam meios suaves e persuasivos de se exercer o poder na Época Moderna, além da coerção pela força teorizada por Weber. O contexto de produção e divulgação dos folhetos seria diretamente ligado ao complexo burocrático e administrativo das monarquias na época, complexo este que permitia a afirmação, também, de outros agentes sociais além dos reis. 
Outros poderes, como os de aristocratas, eclesiásticos, tipógrafos, autores, censores, todos eles envolvidos no processo de escrita e divulgação rápida dos mais diversos eventos e manifestações literárias. ${ }^{6}$

$\mathrm{Na}$ coleção Barbosa Machado encontram-se títulos sobre reis, senhores seculares e eclesiásticos de Portugal. Neles figuram relatos de eventos, elogios oratórios e poéticos, sermões de nascimentos, aniversários, casamentos, funerais, entradas, orações pela saúde, biografias, genealogias, além de autos de reuniōes de cortes e aclamações, notícias de batalhas e cercos militares, manifestos e tratados políticos, missões religiosas, procissões, autos de fé e vilancicos.

Considerar a criação, impressão e divulgação dos folhetos algo diretamente ligado aos poderes na Época Moderna implica também repensar o próprio conceito de representação do poder. Entre vários autores, Carlo Ginzburg nos fornece uma interessante interpretação, a partir da tensão entre "presença" e "ausência" - fazer presente aquilo que não está -, tão própria do fenômeno da representação. Por meio do estudo de relações transculturais, característico de sua abordagem, Ginzburg observa a prevalência da substituição sobre a imitação no esquema representativo. Ao percorrer manifestações encontradas nos colossos da Grécia antiga, nos funerais dos imperadores romanos, ou no culto às efígies régias na Inglaterra $\mathrm{e}$ na França entre a Baixa Idade Média e o Renascimento, o historiador evidencia a perspectiva de se aliviar o trauma da morte mediante a perpetuação ritual do ser vivente - a figura expoente, o rei, o imperador - em uma estátua, máscara ou efígie, que adquiria, assim, um tom sagrado. Nesse sentido, a morte do corpo físico não era o fim da vida do corpo no mundo, pois cabia ao funeral separar definitivamente os mortos dos vivos. Em suma, colossos, estátuas de cera e efígies sagradas seriam espécies de ficçôes da soberania viva do defunto, fosse ele um rei, um imperador, ou mesmo algum nobre de expressão. ${ }^{7}$

Essa dupla perspectiva que associa diretamente as celebrações diversas, as batalhas e sua literatura, ao poder - como defende Bouza Álvarez e em termos de substituição mais que de imitação - segundo o ensaio de Carlo Ginzburg -, sem contudo concebê-las como algo externo e acessório ao que representa, parece bem de acordo ao tempo que estudamos. Em uma sociedade do Antigo Regime, como distinguir aparência e essência, 
representação e natureza do poder, o individual do estamental, o privado do público? Em todos os casos, os extremos interpretativos são perigosos. Mas fica claro que os tratados jurídicos e os decretos administrativos, por exemplo, não podem ser hierarquizados como textos mais relevantes que a elaboração e a descrição de uma festa. Ambas as fontes são significativas para o entendimento do poder na Época Moderna. Os dois tipos de documentos encontram-se presentes na coleção Barbosa Machado.

\section{Coleção preciosa}

Esses três mil opúsculos foram reunidos, classificados, algumas vezes recortados e reduzidos a um único formato, para serem encadernados em grossos volumes, pelo insigne colecionador no século XVIII. Tratando-se de peças de uma coleção, é preciso considerá-las agora sob esse prisma. Krzysztof Pomian concebe os objetos de uma coleção como semióforos, aqueles elementos capazes de fazer a ponte entre o visivel - o mundo dos vivos - e o invisivel - o mundo dos mortos, dos deuses, dos antepassados. Em princípio sem utilidade objetiva no mundo dos vivos, as peças, ao serem reunidas pelo colecionador e retiradas da esfera cotidiana, acabam adquirindo um valor especial, quase sagrado, como pontes possíveis entre dois mundos distantes, qual seja, no espaço - outros países e terras "exóticas", para os objetos naturais -, ou no tempo - presente, passado e futuro. ${ }^{8}$

Dessa forma, os opúsculos e imagens compilados e organizados por Diogo Barbosa Machado possibilitavam ao colecionador e seu público outros eruditos da época - fazer uma ligação entre presente visivel e passado invisivel, pela via da identificação. Ao guardar gravuras e folhetos relativos ao seu presente, o abade também indicava a idéia de que o presente visível tornar-se-ia posteriormente passado invisível, lembrado e preservado como história do reino português. Os folhetos e retratos em si possuíam função informativa, embora efêmera, pois eram produzidos para consumo rápido.

Mas é preciso observar que Diogo Barbosa Machado, com suas ações de recorte, encadernação e preservação, conferia-lhes outro valor, que transcendia o próprio tempo no qual os opúsculos foram produzidos. Seu trabalho consistia na escolha e depuração do que era digno de ser adquirido 
para sobreviver, ultrapassando a condição de escrito efêmero fadado ao desaparecimento. Sem esses cuidados, essa documentação tenderia a extraviar-se. Dispostos em coleção, esses registros tornaram-se fontes que hoje propiciam o conhecimento do passado. De acordo com o arcabouço conceitual de Pomian, os materiais coligidos por Barbosa Machado eram retirados do invisível - o pretérito -, mas se destinavam a outro invisível - o futuro -, pois o ato de salvaguardar objetos permitia que eles fossem expostos ao olhar, não apenas do presente, mas também das gerações vindouras.

O conjunto documental estudado deve ainda ser considerado frente aos demais de seu tempo. A coleção Barbosa Machado diferencia-se em alguns aspectos de outras do mesmo período, como as estudadas por Adalgisa Lugli, Antoine Schnapper e João Carlos Brigola, trabalhos que destacam o interesse dos colecionadores do século XVIII por materiais relativos à história natural. A partir dessas coleções, os autores refletem sobre as mudanças científicas ocorridas na virada do século XVIII para o XIX. Os naturalistas de início e meados do Setecentos queriam mostrar as maravilhas da criação divina - por meio de materiais que representassem o extraordinário, como o chifre de unicórnio ou a mandíbula de um gigante. Já os colecionadores do Oitocentos preocupavam-se em classificar materiais coletados, desvendando assim leis da natureza. ${ }^{9}$

No referente às coleções de história ou antiquárias, percebe-se o predomínio de objetos materiais - moedas, medalhas ou mesmo estampas nos acervos do século XVIII. Acreditava-se que essas peças eram menos passíveis de manipulação. Mas havia também o interesse crescente de colecionadores ligados a ordens religiosas, ou de juristas, em relação aos documentos escritos. Para esses clérigos e juízes, escritos não eram menos verdadeiros que medalhas ou moedas antigas. Mediante crítica documental, era possível estabelecer com rigor a autenticidade dos testemunhos. ${ }^{10}$

A coleção Barbosa Machado caracteriza-se por reunir documentos escritos e históricos, segundo nomenclatura inadequada ao século XVIII, tempo de relativa indistinção entre história e história natural. Desse modo o acervo difere inclusive de outras coleçôes compostas por eruditos próximos ao abade. $\mathrm{O}$ gabinete dos condes da Ericeira, por exemplo, especializava-se em antiguidades, moedas, sobretudo em história natural. Embora mantivesse uma coleção de manuscritos, o duque de Cadaval dedicava-se 
também aos objetos naturais e à numismática. A coleção dos marqueses de Abrantes era referência em medalhas, e o gabinete de D. João V centravase nos objetos de arte e na mineralogia. ${ }^{11}$

Barbosa Machado não se interessava por instrumentos científicos ou objetos naturais, mas por documentos relativos ao passado português, imagens de homens valorosos dessa história e mapas das conquistas lusas. Sua coleção não dizia respeito ao mundo da natureza, mas à história de Portugal. Preocupado com o pretérito lusitano, ele colecionou durante anos documentos referentes a este tempo e a um presente que um dia também se tornaria pregresso. Dispostos em coleção, aqueles documentos permitiam que a memória de eventos e homens continuasse viva. Por sua vez, na coleção, esses folhetos mudavam seu estatuto, tornando-se fontes que permitiam conservar uma relação com o passado, constituindo a memória daqueles homens e eventos, escolhidos por Barbosa Machado para sobreviverem ao tempo.

Mas não tratamos somente desses objetos "sagrados". Ao lado deles, segundo Pomian, estavam os homens semióforos, que se rodeavam de objetos semióforos e com isso aumentavam seu poder em termos de significado: reis, clérigos, príncipes, mecenas. Coleções formadas em palácios, bibliotecas, oficinas, junto aos centros de poder. As semelhanças com as idéias de Ginzburg e Bouza Álvarez são evidentes, agora com o reforço da especificidade do século XVIII. Tempo de florescimento das academias literárias, das bibliotecas, coleções, antiquários, instituições que impulsionaram o afã pela pesquisa, pela compilação e publicação de textos. ${ }^{12}$

\section{Estratégia e gosto}

Tempo da trajetória do nosso Diogo, o colecionador. Isabel Ferreira da Mota comenta a ascensão social dos irmãos Barbosa Machado, vindos das camadas médias de Lisboa. Todos eles ascenderam através das letras. Inácio Barbosa Machado (1686-1766) foi juiz de fora em 1720 na Bahia, onde participou da Academia dos Esquecidos, fundada em 1724. Com o falecimento da esposa, ingressou no clero em 1734. Aposentado como desembargador da Relação do Porto em 1748, foi nomeado depois cronista-mor do reino. Membro da Academia Real de História, ele deixou, ao 
morrer, uma biblioteca com mais de dois mil volumes, anexada à de Diogo, pois os irmãos viviam na mesma casa. O outro irmão, José Barbosa (16741750), ingressou na ordem dos teatinos, distinguindo-se posteriormente ante D. João V como orador célebre e cronista oficial da casa de Bragança. Ele também foi membro da Academia Real de História. Ambos os irmãos foram autores de várias obras. Entre os livros que compõem a coleção pessoal de Diogo Barbosa Machado há dois inteiramente dedicados aos sermões escritos por seu irmão mais velho. ${ }^{13}$

Diogo Barbosa Machado estudou em Lisboa e Coimbra, onde se matriculou na faculdade de direito canônico, mas não prosseguiu o curso, retornando à capital. Obteve então, pela ação de um filho bastardo do duque de Cadaval, um pequeno benefício no bispado de Lamego que lhe permitiu comprar livros e permanecer em Lisboa. Recebeu ordens de presbítero em 1724 como oratoriano. ${ }^{14}$ Por iniciativa do marquês de Abrantes, seu protetor, Barbosa Machado foi nomeado, em 1728, abade da Igreja de Santo Adriāo de Sever, no bispado do Porto. Este segundo benefício foi muito mais significativo que o primeiro. Após permanecer algum tempo em Sever, Diogo Barbosa voltou a Lisboa, pedindo ao marquês para residir definitivamente na capital. $\mathrm{O}$ marquês de Abrantes recorreu então ao papa, para um aumento da pensão e dos dízimos devidos ao abade. $\mathrm{O}$ nosso Diogo conseguiu assim regressar a Lisboa, dedicandose exclusivamente às atividades de escritor e colecionador, tarefas não compatíveis com a vida na distante abadia - que provavelmente não passou de uma construção de madeira -, tampouco com o afastamento do maior centro cultural e do poder em Portugal. ${ }^{15}$

A nova renda permitiu a Diogo Barbosa Machado aumentar sua preciosa biblioteca. Naquele tempo, ele já era membro da Academia Real desde 1720 - provavelmente graças também ao marquês de Abrantes. A instituição fundada por D. João $\mathrm{V}$ estava interessada em escrever a história do reino português e promover as glórias de Portugal na Europa, no entanto, nela o papel de Diogo parecia ser tímido, pelas poucas vezes que o abade de Sever foi citado nos documentos. Na Historia da Academia Real da História Portuguesa, Manoel Telles da Sylva reuniu atas de reuniōes e conferências do primeiro ano de funcionamento da instituição. Diogo aparece uma única vez, ao levantar uma questão a respeito da morte de D. 
Sebastião na batalha de Alcácer Quibir. A mesma obra leva a crer que, naquele grupo erudito, alguns membros destacavam-se mais que outros. Esses em geral faziam parte dos grandes da nobreza - como Francisco Xavier de Meneses, conde de Ericeira, e Francisco Paulo de Portugal e Castro, marquês de Valença - ou eram eclesiásticos responsáveis pela fundação da Academia - como Manoel Caetano de Sousa. ${ }^{16}$

Diogo Barbosa Machado foi um dos cinqüenta primeiros acadêmicos que fundaram o círculo literário, designado para escrever as histórias dos reinados de D. Sebastiáo, do cardeal-rei D. Henrique e dos reis Habsburgos de Portugal. Ferreira da Mota comenta que o então futuro abade entrou na Academia sem qualquer obra publicada, com um currículo vulgar. No primeiro tomo que escreveu sobre as memórias da história de Portugal no reinado de D. Sebastião, a dedicatória foi para D. João V. Mas, no prólogo, Barbosa Machado referia-se ao marquês de Abrantes. No fim da vida, bastante idoso, autor de várias obras, ofereceu a D. José I sua biblioteca. Nesse tempo, já tinha ascendido a uma posição que lhe permitia ter seus próprios clientes, entre eles Francisco José da Serra, autor de sua oração fúnebre. ${ }^{17}$

Não é difícil relacionar a coleção à trajetória, valores e objetivos de vida de seu artífice. Os opúsculos recortados e encadernados pelo abade indicam o próprio perfil de Diogo Barbosa Machado, em suas estratégias de ascensão social - não obstante o indubitável gosto colecionista pela história, característico do Setecentos europeu. Homem semióforo, Barbosa Machado transitava entre o visível e o invisível. Ao obter e comprar folhetos por meios diversos, o colecionador retirava essas obras do seu universo de circulação, inviabilizando sua leitura imediata. Não obstante, ele aumentava o significado dos opúsculos de sua coleção com a classificação, a impressão de frontispícios especiais, com seus ex-libris e sumários que estabeleciam a ordem dos títulos, tudo elaborado com capricho e organização. Conferia às peças destacadas e integradas nos álbuns um outro valor, como intermediárias entre o mundo profano e outro sagrado, o mundo dos mortos, "semi-deuses", dos reis e insignes de Portugal. As estampas e opúsculos serviam, assim, como relíquias, imagens preciosas do além, produzindo uma sensação mista de proximidade e distância em quem as observasse. 
Ao reconstruir episódios de memórias alheias, Barbosa Machado também configurava sua própria história, seu poder em termos de significado. É assim que entendemos sua ascensão social. Lembrando as idéias de Ginzburg sobre a representação do poder como substituição, o abade, ao confeccionar sua coleção particular, não apenas produzia registros acessórios ao conhecimento de personagens ilustres antepassadas, mas de fato tornava-as presentes naquele mundo setecentista. Ao mesmo tempo, ele aumentava suas possibilidades de obtenção de patrocínios e mercês, que lhe permitiam continuar sua coleção, pois as paixôes e os interesses não são excludentes. Em outras palavras, como detentor daquela memória insigne, Barbosa Machado substituía essas ilustres personagens - falecidas ou não - em sua sociedade.

Do filho bastardo do duque, ao marquês, ao rei. $\mathrm{O}$ esmero com que a coleção foi feita é análogo ao bem sucedido destino do abade de Sever, considerando suas modestas origens. A doação da coleção à Real Biblioteca expressa bem o coroamento de uma trajetória. Entre 1770 e 1772, Diogo Barbosa Machado prestou serviço ao rei mecenas, maior dos homens semióforos de Portugal, interessado em associar sua imagem régia à preciosa coleção. O rei, agradecido, concede-lhe mercê em forma de pensão. $\mathrm{Na}$ Real Biblioteca, a coleção acompanha e constrói a imagem póstuma de Barbosa Machado. Esta memória atravessou o Atlântico, viajando com a Corte para o Brasil. Memória dos reis, nobres, heróis de batalha, sacerdotes insignes e santos. E Diogo Barbosa Machado junto a eles. Essas histórias conferiam superioridade a este colecionador apaixonado, como ficção de sua soberania viva.

\section{Em ordem}

Entramos assim neste universo de inclusão e exclusão social, procurando perceber os critérios de ordenação e classificação empregados pelo abade na confecção desse material em aproximadamente 145 volumes. Essas são as matérias, como aparecem no catálogo manuscrito pelo próprio Diogo Barbosa Machado:

Genethliacos dos Reis, Rainhas e Principes de Portugal, 5 tomos. Aplausos dos Anos de Reis, Rainhas e Principes de Portugal, 2 tomos. 
Entradas em Lisboa de Reis e Rainhas, 2 tomos.

Epithalâmios de Reis e Rainhas de Portugal, 5 tomos.

Elogios dos Reis, Rainhas e Príncipes de Portugal, 4 tomos.

Aplausos Oratórios e Poéticos pela Saúde dos Reis, 1 tomo.

Últimas Ações e Exéquias de Reis, Rainhas e Príncipes de Portugal, 3 tomos.

Elogios Fúnebres dos Reis, Rainhas e Principes de Portugal, 4 tomos.

Notícias Militares de D. João IV, 2 tomos.

Notícias Militares de D. Afonso VI, 3 tomos.

Notícias Militares de D. Pedro II, 2 tomos.

Notícias Militares de D. João V, 2 tomos.

Notícias Militares de D. José I, 1 tomo.

Notícias Militares da India Oriental, 3 tomos.

Notícias Militares da América, 1 tomo.

Notícias Militares da África, 1 tomo.

História dos Cercos que Sustentaram os Portugueses nas Quatro Partes do Mundo, 5 tomos.

Aplausos Genethliacos de Fidalgos Portugueses, 1 tomo.

Epithalamios de Duques, Marqueses e Condes de Portugal, 3 tomos.

Elogios de Duques, Marqueses e Condes de Portugal, 2 tomos.

Elogios Fúnebres de Duques, Marqueses e Condes de Portugal, 4 tomos.

Elogios Fúnebres de Duquesas e Marquesas de Portugal, 1 tomo.

Elogios Oratórios e Poéticos de Cardeais e Bispos, 2 tomos.

Elogios Fúnebres de Cardeais e Arcebispos de Portugal, 1 tomo.

Elogios Fúnebres de Eclesiásticos Portugueses, 3 tomos. (falta o 40)

Elogios Fúnebres de Diversos Portugueses, 2 tomos.

Elogios Históricos e Poéticos de Eclesiásticos e Seculares, 1 tomo.

Manifestos de Portugal, 3 tomos.

Tratados de Pazes Celebradas em Diversas Cortes, 2 tomos.

Autos de Cortes e Levantamento de Reis, 2 tomos.

Notícia Genealógica da Casa Real, 1 tomo.

Notícia Genealógica de Familias Portuguesas, 2 tomos.

Notícia das Missóes Orientais, 2 tomos.

Noticia de Procissóes e Triunfos Sagrados, 4 tomos.

Sermões Vários de D. José Barbosa, 2 tomos.

Sermões na Aclamação Del Rey D. João IV, 2 tomos. 
Sermões do Nascimento de Reis e Principes de Portugal, 4 tomos.

Sermóes de Desposórios de Príncipes de Portugal, 1 tomo.

Sermóes Gratulatórios pela vida e Saúde dos Reis de Portugal, 5 tomos.

Sermóes de Exéquias dos Reis de Portugal, 7 tomos.

Sermóes de Exéquias de Rainhas de Portugal, 3 tomos.

Sermóes de Exéquias de Príncipes e Infantes de Portugal, 3 tomos.

Sermóes de Exéquias de Duques de Portugal, 1 tomo.

Sermões de Exéquias de Marqueses e Condes de Portugal, 2 tomos.

Sermões de Exéquias de Duquesas, Marquesas e Condessas de Portugal, 1 tomo.

Sermões de Exéquias de Senhoras de Portugal, 1 tomo.

Sermões de Exéquias de Varôes Portugueses, 1 tomo.

Sermões de Exéquias de Cardeais e Arcebispos Portugueses, 2 tomos.

Sermóes de Exéquias de Bispos Portugueses, 3 tomos.

Sermóes de Exéquias de Eclesiásticos Portugueses, 1 tomo.

Sermóes de Exéquias de Fidalgos Portugueses, 1 tomo.

Sermões Pregados nos Autos de Fé celebrados em Lisboa, Coimbra, Évora e Goa, 6 tomos. (Falta o 20)

Vilancicos da Festa do Natal Cantados na Capela Real desde o Ano de 1640 até 1715,4 tomos.

Vilancicos da Conceição de N. Senhora Cantados na Capela Real desde o Ano de 1652 até 1715, 3 tomos.

Vilancicos da Festa dos Santos Reis Cantados na Capela Real desde o Ano de 1646 até 1716, 3 tomos.

Vilancicos na Festa de São Vicente cantados na Catedral de Lisboa desde o Ano de 1700 até 1723, 1 tomo.

Vilancicos de Santa Cecília do Ano de 1702 até 1722, 1 tomo.

Vilancicos de São Gonçalo do ano de 1707 até 1722, 1 tomo.

Vilancicos de Várias Festividades, 1 tomo.

Notícias das Embaixadas que os Reis de Portugal mandaram aos Soberanos da Europa, 3 tomos (omitidos no catálogo). ${ }^{18}$

A compilação de folhetos é a parte mais volumosa da coleção pessoal do abade de Sever. Ela apresenta não somente opúsculos impressos e manuscritos sobre a monarquia, a nobreza e os eclesiásticos portugueses, mas também notícias sobre festas, batalhas e ainda relatos de missões que acon- 
teceram nas possessões portuguesas da Ásia, América e África. Os folhetos se encontram, predominantemente, em português e espanhol, mas também há vários em francês, inglês, latim, alemão ou italiano. Os locais de publicação também são variados: há opúsculos impressos em Lisboa, Madri, Barcelona, Roma, Luca, Paris, entre muitas cidades. Difícil resistir à tentação de comentar alguns desses ricos documentos em separado - o que fugiria aos propósitos deste estudo.

Contudo, é interessante observar como Barbosa Machado não apenas selecionou e ordenou este material, mas também interferiu nele, deixando sua marca. Em relação aos opúsculos, ele não raro repetiu-os em volumes de temáticas diferentes; também os dividiu, dispondo partes deles em volumes separados, ou acrescentou mapas, plantas de cidades, desenhos de batalhas, até mesmo corrigindo palavras e erros tipográficos. Seu empenho em organizar este material é evidente no cuidado em preparar listas manuscritas com os títulos dos folhetos de um determinado volume - livro, dispondo-as no início de cada tomo da coleção. Produziu assim índices de consulta.

Não faltam na coleção folhetos, feitos por pares de Barbosa Machado, membros da Academia Real de História, incluindo-se o próprio abade de Sever. Sobretudo em volumes dedicados aos aniversários de reis e rainhas de Portugal, há várias orações e elogios recitados por acadêmicos aos monarcas.

Torna-se difícil definir exatamente a maneira como Barbosa Machado conseguiu reunir essa quantidade de documentos. Sabemos por informaçóes concernentes à tipografia, ao idioma ou ao local de publicação que a maioria dos opúsculos foi produzida em Portugal, mas há muitos outros que vieram de fora do reino. Mesmo entre os opúsculos lusos, por exemplo, há alguns raros e outros que datam do século XVI. Como o abade de Sever tinha acesso a esses documentos? Em alguns casos, Diogo Barbosa Machado comprava esses materiais e ainda mandava-os vir do estrangeiro. Essa prática era comum, uma vez que vários letrados da época, como Diogo de Mendonça Corte Real, ocupavam cargos administrativos, viajavam constantemente, e assim entravam em contato com eruditos de outros países.

Adentremos na ordenação dos opúsculos coligidos pelo abade de Sever. Observamos que Barbosa Machado aplicou de início critérios referentes 
aos gêneros literários e à natureza do evento (sermões, panegíricos, entradas, exéquias etc) e à personagem central do documento (reis, princesas, grandes de Portugal etc), utilizando também a classificação de gênero sexual. Em seguida valeu-se da cronologia para dividir mais os volumes: "de 1640 a 1668", de "1669 a 1706", "no ano de 1750", por exemplo. A ordem temática, como se vê, vem antes da cronológica; trata-se de determinar as características, de agrupar unidades textuais em corpos maiores. ${ }^{19}$ A classificação espacial também ocorreu, ao identificar tomos a eventos na Ásia, América ou África, partes do império português. Tudo leva a crer que o abade amealhou primeiramente todo o conjunto documental, ou a maior parte dele, para depois encaderná-lo. O folheto mais antigo data de 1505 e o mais recente é de 1770, ano de início da transferência dos volumes à Real Biblioteca.

Mas existe ainda outro aspecto que convém observar, referente à disposição dos volumes no catálogo manuscrito pelo próprio abade. Embora eles não sejam numerados, essa disposição pode dar conta também dos critérios de relevância empregados por Diogo Barbosa Machado. Nesta ordem, observa-se que os reis aparecem em primeiro lugar - como nos retratos, outro rico conjunto documental desta biblioteca. ${ }^{20}$ Os reis nascem (genetlíacos), aniversariam, "entram" - ou dominam - a capital do reino, casam-se (epitalâmios), passam por intempéries de saúde (quando se destacam os episódios concernentes à agonia de D. João V) e morrem (exéquias), tudo isso em meio a muitos elogios (...) No Antigo Regime, os reis personificavam o Estado e muitas vezes identificavam-se à sociedade mediante a exposição de seus ciclos de vida, para além de qualquer análise sobre a centralização política e administrativa do poder. ${ }^{21}$

Em seguida, surgem os aspectos militares, ainda que divididos cronologicamente em reinados. Os feitos de guerra propagam-se pelo império: Índia, América, África. Note-se a ordem peculiar entre os continentes, na qual volumes referentes à Ásia vêm antes de América e África, contrariando a lógica que destaca a importância econômica e geopolítica do Brasil na conjuntura do século XVIII. Por sua vez, a ordem temporal das conquistas lusitanas também não foi seguida pelo abade, pois neste caso a África viria antes de Ásia e América. Parece que o valor predominante - que também ocorreu nos retratos de governadores ultramarinos - foi o maior prestígio 
social da Índia e do Oriente em relação às outras praças. Essa literatura militar enaltecia não apenas os reis, mas principalmente os bravos portugueses - nobres ou plebeus - que lutaram ao lado da monarquia, provando seu valor e fidelidade, e assim buscavam alguma mercê - uma comenda militar ou cargo - mediante o ethos da guerra tão valorizado naquele tempo. ${ }^{22}$

Essa é a ponte com o mundo aristocrático, seguindo também a lógica cíclica da vida: nascimentos, casamentos, mortes. Seguem os folhetos relativos aos clérigos e prelados que, embora não nascessem naquela condição, adquiriam-na ao longo da vida e morriam como tais. Os panfletos e libelos políticos (agrupados com o significativo título de "manifestos de Portugal"), os tratados e as atas das assembléias de cortes, aparecem mesclados a esse bloco, ainda antes das notícias genealógicas da casa real e de casas nobres. Observa-se nesse subconjunto a relativa indistinção entre as elites secular e eclesiástica, as idéias políticas e as questôes religiosas, divisão de campos mais própria da época contemporânea que do tempo de Barbosa Machado. ${ }^{23}$

Entretanto, as missões no Oriente e as procissões abrem caminho para a documentação de perfil acentuadamente religioso. Mais uma vez, a ordem dos sermões inicia-se com temas relativos aos reis, primeiramente proferidos pelo irmão de Diogo, José Barbosa Machado, cronista oficial dos Bragança - a marca pessoal e familiar aí se faz presente. Em seguida, a temática da Restauração na aclamação de D. João IV, sucedida pelos sermões de nascimentos, casamentos, mortes, primeiramente dos reis, depois de nobres e eclesiásticos portugueses. Finaliza-se a coleção com sermões pregados nos autos de fé, e os vilancicos, espécies de canções ligadas nesse caso - às festas de santos. Da purificação das almas à santidade... Mais uma vez, as interfaces entre questôes políticas presentes nos sermões, argumentos providencialistas e assuntos de ordem moral são bastante fortes para o entendimento do universo cultural luso no Antigo Regime, contraditando idéias comuns na historiografia tradicional acerca de um Estado moderno e laico a partir do século XVI. ${ }^{24}$

Não obstante, nota-se uma perspectiva mais secular de organização dos volumes, coerente ao contexto do século XVIII português, e à própria inserção de Diogo Barbosa Machado na Academia Real de História. Os reis, a guerra, os nobres, são dispostos nos primeiros lugares. A ordem dos 
folhetos também pressupõe a inclusão e a exclusão social. Neste aspecto é evidente o caráter elitista da coleção Barbosa Machado, relacionado à própria natureza da documentação, que expressa um mundo de príncipes, aristocratas e clérigos destacados.

Igualmente torna-se evidente a postura quase enciclopédica de incorporação de documentos políticos referentes a traumas já superados na história de Portugal em meados do século XVIII, como, por exemplo, em relação às conjunturas da Restauração e da Guerra de Sucessão da Espanha, que agregam documentos castelhanos contra Portugal. Até mesmo os jesuítas aparecem muito, desde a criação da Companhia até o tempo do próprio abade. Isso evidencia os aspectos particulares da coleção, algumas vezes em desacordo com a política de Sebastiāo José de Carvalho e Melo no reinado de D. José $\mathrm{I}^{25}$

Vários conhecidos documentos que expressam a polêmica entre os filhos do Restaurador, D. Afonso VI e o infante D. Pedro, não foram incluídos na coleção. Nesse caso, a imagem régia seria depreciada, particularmente a de D. Pedro II, pai de D. João V e avô de D. José I, que teria usurpado o trono ao irmão. Este e outros aspectos conduzem à inflexão de que a coleção foi montada ao longo do tempo para ser oferecida "ao rei”, e assim seus critérios de inclusão e exclusão procuravam atender também a este objetivo, evitando conflito em relação aos monarcas e demais personagens de destaque.

Portanto, a coleção de opúsculos organizada por Diogo Barbosa Machado demonstra com clareza a ordem de um tempo, em princípio do próprio abade que viveu entre os reinados de D. Pedro II, D. João V e D. José I. Tempo de fortalecimento da dinastia brigantina no exercício do poder régio, de incremento da idéia de história, do interesse da própria monarquia por documentos relativos à sua história e à história do reino, de uma relativa secularização do poder, do afã das coleções e suas taxionomias, das academias literárias e da preservação dos monumentos. Tempo também de valorização em Portugal da imagem do poder régio - é flagrante o número maior de opúsculos referentes aos reinados de D. João V, sobretudo de D. José I, em relação aos antecessores, e isso ocorreu não somente devido à facilidade na oferta dos documentos captados por Bar- 
bosa Machado, mas também à maior produção literária de peças laudatórias e comemorativas nesse período. ${ }^{26}$

Contudo, é preciso não esquecer da ação individual do abade de Sever, deixando sua marca indelével nos folhetos que organizou. Nela se expressam suas expectativas de ascensão social, sua paixão colecionista e sua escrita particular da história de Portugal e do império.

\section{Várias histórias}

Mas a coleção Barbosa Machado também se refere a diversos tempos. Um tempo passado, dos folhetos produzidos desde o século XVI até o XVIII, de uma cultura política do Portugal no Antigo Regime, do início ao fim da Idade Moderna. Desconsiderar esse aspecto significaria negligenciar a importância da coleção como acervo de fontes especialíssimas, e as possibilidades de pesquisa para historiadores interessados nesse rico conjunto documental, apesar das mutilaçōes e ausências de páginas em alguns documentos.

Por lidar com a memória preservada e selecionada, essa coleção também se relaciona a outros tempos, futuros ao próprio Diogo Barbosa Machado, ao construir sua imagem póstuma. A pesquisa considera o processo de restauração sofrido pela coleção de opúsculos em meados do século $\mathrm{XX}$, sua catalogação, as possíveis intervenções, isto é, a constituição desta coleção como acervo próprio. Para Jacques Le Goff, a memória é sempre atual, revivificada, ao desempenhar alguma função social. ${ }^{27}$ Entre o tempo da Alta Idade Moderna - o que mais uma vez lembra Bouza Álvarez e sua civilização da escrita -, o tempo da formação da coleção e da cultura mais enciclopédica, e o século XX, quando os volumes foram restaurados e estudados, operaram-se mudanças na idéia de história.

A história como "mestra da vida" era certamente presente nas tantas entradas de reis e genealogias dos "grandes", repletas de alegorias antigas e feitos providenciais, o futuro grandioso da monarquia previsto em vaticínios e escatologias, à semelhança dos impérios antigos. Em muitos opúsculos, exemplos de personagens antigas aparecem entremeados às histórias dos heróis dos séculos XVI, XVII e XVIII, numa confusão de épocas que freqüentemente rompia as barreiras cronológicas, fazendo de tudo um só passado. ${ }^{28}$ 
A historia magistra pressupunha a admissão da constância e a invariabilidade da natureza humana, mas também um tempo mais lento no referente às transformaçóes sociais, permitindo que exemplos de personagens pretéritas continuassem úteis e válidos no presente, limitando o que seria possível experimentar no futuro. Desse modo, a coleção Barbosa Machado não é apenas compilação de personagens e eventos, mas reunião de exemplos morais: reis portugueses valorosos, súditos fiéis e prelados virtuosos.

Para Barbosa Machado e outros eruditos da época, o estudo do passado perpetuava a memória, ao trazer heróis novamente à vida. A história era então um gênero ligado à exaltação dos grandes homens, uma elegia a sua glória. Segundo Manuel Teles da Sylva, os homens ilustres foram sepultados nos arquivos do reino graças ao esquecimento e à negligência. ${ }^{29}$ Portanto, era preciso conhecer os arquivos, organizá-los e ter acesso aos vestígios do passado. Barbosa Machado tomou para si a tarefa de fazer justiça àqueles homens e mulheres dignos. Hoje conservamos praticamente tudo o que nos chega do passado, no entanto, a cultura histórica setecentista parecia ser mais criteriosa. Como lembra Blandine Kriegel, para eruditos dos séculos XVIII nem todos os textos eram documentos merecedores de sobreviver ao tempo. Diferente do nosso universo, para o qual todos os tipos de texto são fontes, naquele mundo erudito o movimento era inverso, de estreitamento e redução. ${ }^{30}$

Tratava-se de uma depuração: apenas o exemplar para gerações futuras deveria sobreviver ao tempo, merecendo imortalidade. A definição no Vocabulário Português e Latino do padre Raphael Bluteau - importante erudito da época e também membro da Academia Real da História - apresenta este significado:

Mais particularmente, historia he narração de cousas memoráveis, que tem acontecido em algum lugar, em certo tempo, e com certas pessoas, ou naçõens. (...) A historia he a testemunha do tempo, a luz da verdade, a vida da memória, a mestra da vida, e a mensageira da Antiguidade. ${ }^{31}$

A história como mestra da vida ligava presente e passado por meio de exemplos ensinados. Nessa visão, os atos de varões insignes e reis de outrora inspiravam a fidelidade dos súditos e fiéis portugueses do século XVIII. No entanto, essa concepção de história relaciona-se também ao futuro. Os homens valorosos precisavam ser tirados do esquecimento por merecerem 
a eternidade, pois as ações pretéritas serviam como espelho e estímulo para futuras gerações. Portanto, colecionar era um modo de se ter o passado bem perto, sentindo-o e preservando-o contra a corrupção do tempo. Folhetos e imagens colecionadas deixavam viva assim a memória de homens pregressos, educando por sua vez os do presente e do porvir.

Por outro lado, parece que havia por parte do abade interesse em perpetuar a lembrança de seu próprio trabalho. Com este intuito incluiu dois retratos seus na coleção de estampas. E aceitou doar, em troca de uma mercê em forma de pensão - ação própria da cultura política do Antigo Regime - sua livraria à Real Biblioteca. Ainda ali, era patente a sincronia entre aquelas experiências passadas e gloriosas, e o horizonte de expectativas do abade, que compunha a coleção para ser ofertada ao rei. Portanto, a história como mestra da vida pode ser verificada, ainda, na ação do colecionador Barbosa Machado. História e memória, juntas.Todavia, como vimos, elas aparecem mescladas entre classificaçôes temáticas e uma ordenação cronológica que discriminava os tempos em progressão. Este é um aspecto importante, a ser desenvolvido posteriormente, a distinguir as transformações ocorridas no século XVIII na própria concepção de história doravante mais ligada à idéia de progresso, segundo a clássica análise de Reinhart Koselleck. ${ }^{32}$

Ao final do século XIX, na Biblioteca Nacional do Brasil, a coleção de retratos passou por um processo de restauração e catalogação, sob o comando do diretor Benjamin Franklin Ramiz Galvão (1870-1882) e do chefe da recém-criada seção de estampas José Zepherino Brum. Entusiasta da obra de Diogo Barbosa Machado, Ramiz Galvão abriu o primeiro volume dos Anais da Biblioteca Nacional - outra iniciativa sua - com um artigo sobre o bibliófilo setecentista. Na gestão do barão de Ramiz a Biblioteca Nacional passou por uma reforma inspirada nas bibliotecas européias à época. Com a filosofia da história e as novas experiências contemporâneas, a idéia de um passado exemplar como referência ao futuro tornou-se menos evidente, mas nem por isso desapareceu. ${ }^{33}$

Contudo, é interessante destacar o ocorrido com os opúsculos. Em meados do século XX, a coleção de folhetos também foi restaurada e catalogada. A bibliotecária Rosemarie Erika Horch comenta que os volumes estavam "caindo aos pedaços", com os suportes originais de couro amarra- 
dos. As janelas - buracos feitos nos papéis que envolviam os folhetos para que fossem uniformizados em tamanho para encadernação - já existiam. No entanto, apresentavam aspecto grosseiro, sobretudo no verso. Foram feitos então novos suportes, com folhas de papel japonês coladas sobre as originais, dos dois lados. As novas páginas foram numeradas com carimbos. No presente, essa restauração obedeceria a outros critérios técnicos. ${ }^{34}$

Rosemarie Horch estudou na Alemanha e realizou extenso trabalho com os incunábulos da Biblioteca Nacional. Em 1955 foi convidada pela chefe da seção de obras raras, Vera Leão de Andrade, para catalogar a coleção de opúsculos de Barbosa Machado. O trabalho havia sido iniciado por Ramiz Galvão décadas antes, mas Horch decidiu seguir outra ordem, diversa também da empregada pelo abade de Sever. Durante sua licençamaternidade, e quando passou a residir em São Paulo, as tarefas continuaram na casa da bibliotecária, quatro ou cinco volumes por mês retirados da Biblioteca Nacional, depois devolvidos. Para as informaçóes adicionais, Horch consultou a Bibliotheca Lusitana, do próprio Diogo Barbosa Machado, confrontando-a a outras obras de referência expressivas, em trabalho solitário e artesanal que durou até $1960 .^{35}$

O trabalho da funcionária Rosemarie Horch inscreve-se na esteira de transformaçôes ocorridas na Biblioteca Nacional nas gestōes dos diretores Rodolfo Garcia (1932-1945) e Rubens Borba de Morais (1945-1947). Nesse tempo, o curso de biblioteconomia - fornecido pela instituição a partir de 1915 - foi reestruturado, seguindo modelo norte-americano diferente do humanismo presente na École de Chartes, que norteava a atuação dos bibliotecários desde Ramiz Galvão. Em 1944, iniciou-se uma reforma administrativa, com a criação de novas divisões e da seção de obras raras. E as publicações também foram incrementadas, principalmente pelo incentivo à série Documentos Históricos. ${ }^{36}$

Primeiro bibliotecário a assumir a direção da Biblioteca Nacional, Borba de Morais expunha seu plano de ação: reorganização técnica dos serviços, início da classificação do acervo baseada em normas universais o método Dewey -, criação de serviço especial para livros raros, limpeza e desinfecção dos livros. No Brasil, contou com a ajuda dos historiadores Sérgio Buarque de Holanda e José Honório Rodrigues, e do literato Josué Montello. Valendo-se da experiência como diretor da Biblioteca das Na- 
ções Unidas em Nova York, Borba de Morais trouxe especialistas norteamericanos, entre eles William Jackson, que apresentou parecer desolador sobre o estado dos livros raros, especialmente os que integravam a Real Biblioteca. Chegou a sugerir que os documentos fossem restaurados nos Estados Unidos ...

Nesse contexto insere-se o trabalho com a coleção Barbosa Machado, em meados do século XX. Borba de Morais dirigira anteriormente a Biblioteca Municipal de São Paulo - atual Mário de Andrade - caracterizada pelo incentivo à modernização das bibliotecas sob influxo do pragmatismo norte-americano, em contraposição à influência francesa, erudita e generalista, então vigente na Biblioteca Nacional. $\mathrm{O}$ termo documentação e a concepção do bibliotecário como servo dos servos da ciência cresciam em importância. Enquanto o bibliotecário tradicional seria guardião do acervo, com conhecimentos enciclopédicos, o bibliotecário moderno, mediante organização técnica dos materiais bibliográficos e seu uso, orientava os leitores. Esse novo pesquisador imparcial, especialista, seguia técnicas de acordo com a nova ciência da informação: a biblioteconomia. ${ }^{37}$

O catálogo dos opúsculos foi publicado nos Anais da Biblioteca $\mathrm{Na}$ cional entre 1974 e 1988, em oito volumes, com início na gestão de Jannice Monte-Mór (1971-1979), outro momento forte de reestruturação da Biblioteca Nacional. Antes, já haviam sido editados catálogos em separata dos vilancicos, dos sermões de autos de fé, e uma "brasiliana" da coleção Barbosa Machado. ${ }^{38}$

Poderíamos prosseguir no detalhamento de mudanças administrativas e realizaçōes na Biblioteca, no entanto, importa observar que a impressão das peças originais (os opúsculos), sua confecção em conjunto documental (a coleção) e a trajetória deste acervo podem ser relacionadas a diferentes regimes de historicidade, na acepção de François Hartog. Para formular esta noção, o historiador parte das idéias de Claude Lévi-Strauss. Com seu apelo a uma teoria da relatividade generalizada, o antropólogo elaborou ampla reflexão sobre a diversidade de culturas, no texto produzido em meio à descolonização mundial. Hartog também se vale de Marshall Sahlins, ao estudar as viagens do capitão James Cook em seus embates com ilhéus do Pacífico. Para este antropólogo norte-americano, a proposta da antropologia histórica, materializada na expressão estrutura da con- 
juntura, pressupunha maior atenção às diferentes formas de história. $\mathrm{O}$ historiador francês familiarizou-se ainda com as categorias meta-históricas da experiência e da expectativa de Koselleck. Desse modo, a noção de regime de historicidade podia beneficiar-se de um diálogo de Sahlins com Koselleck, da antropologia com a história. ${ }^{39}$

Segundo François Hartog, há várias ordens do tempo, segundo lugares e tempos. Um regime de historicidade pode significar o modo como uma sociedade trata seu passado, a consciência de si mesma. Na esteira de Lévi-Strauss, a noção nega uma historicidade idêntica a todas as sociedades. Ao comparar tipos de história diferentes, evidencia modos de relação com o tempo: formas de experiência, aqui e ali, hoje e ontem. Portanto, a hipótese do regime de historicidade atua sobre vários tempos, instaurando um vai e vem entre presente e passado, ou melhor, passados, eventualmente distantes no tempo e no espaço. Partindo de diversas experiências do tempo, o regime de historicidade torna-se um instrumento heurístico, ajudando a melhor apreender, não o tempo, todos os tempos ou o todo do tempo, mas principalmente momentos de crise do tempo. ${ }^{40}$

Nesse sentido, Hartog alude à crise do "regime moderno" de historicidade no século XX. Após duas guerras mundiais, a história como progresso e a ênfase utópica no futuro cederiam lugar a uma preocupação com o presente, ao incremento da idéia de memória e da conservação do patrimônio histórico. Evidencia-se assim a importância dos arquivos como conjuntos de documentos, parte essencial do patrimônio nacional. Mas o tema do nacional perde evidência, em contraposição a formas renovadas de história ciência, que têm por horizonte o materialismo histórico, o quantitativo, o serial, e por instrumento o computador. Passando do prospectivo ao retrospectivo, os indivíduos munem-se de genealogias, as empresas de arquivos. Uma nova forma de historia magistra - que lida também com o futuro - é assim retomada. Uma historia magistra que não deixa de exprimir o "regime moderno", mas que articula de outro modo as categorias temporais. ${ }^{41}$

O presentismo contemporâneo definido por Hartog pode ser associado às reformas operadas na Biblioteca Nacional, e aos processos de catalogação e restauração dos opúsculos de Diogo Barbosa Machado. Como vimos, a ordem seguida no catálogo publicado nos Anais da Biblioteca 
Nacional não foi a efetivada pelo abade. Nesta nova ordenação, a cronologia foi o critério predominante, os opúsculos arrolados segundo datas de edição ou anos referentes aos assuntos de cada folheto, com o fito de facilitar ao pesquisador a consulta direta aos documentos. Observemos a importância das datas e eventos nesse regime de historicidade, que discrimina assim vários passados, e lembremos que o acadêmico real tinha priorizado outrora a classificação temática.

Portanto, a nova distribuição dos folhetos em catálogo descaracterizou o caráter de coleção do conjunto documental, pois a perspectiva principal do abade de Sever somente é vislumbrada mediante manuseio dos próprios volumes. A mesma relativa desconsideração com o trabalho do colecionador pode ser verificada na restauração dos tomos; ao refazer encadernações, suportes e janelas, inutilizou o material original e pôs em perigo sua integridade. Todavia, esse novo regime de historicidade possibilitou a conservação da coleção enquanto patrimônio, de maneira diferente do trabalho encetado por Barbosa Machado. Vale lembrar o contexto em que essas intervenções foram feitas, com opiniōes de especialistas estrangeiros, sugestão de deslocamento do acervo, e o afã técnico e administrativo que envolvia a nossa Biblioteca Nacional. Tudo isso em meio ao atribulado processo político vivido no Brasil, entre as décadas de quarenta e setenta do século passado. Os temas do nacional, da liberdade, do progresso técnico, da cronologia e da conservação do patrimônio histórico se entrecruzavam, aspectos que não vamos aprofundar aqui.

\section{$\mathrm{Na}$ fissura do tempo}

Contudo, cabe considerar agora essa mescla de temas e historicidades, por vezes não excludentes entre si, para enfatizar algo desenvolvido por Hartog, mas inspirado na filosofia de Hannah Arendt. Esse movimento permitirá nova remissão do estudo ao tempo específico do próprio Diogo Barbosa Machado, desta vez acrescida de novo tema, mais próprio ao momento em que ele elaborava sua preciosa coleção, depois ofertada ao rei.

A ruptura de continuidade podia dar ao homem o sentimento de pertencer a duas eras. De um lado um passado não abolido nem esquecido, de outro um advir sem expressão mais definida. Um tempo desorien- 
tado, situado entre abismos, entre duas eras. $\mathrm{Na}$ abertura de Entre o Passado e o Futuro, Arendt introduz o conceito de "brecha" em torno do qual se organizou o livro, como um estranho entre dois no tempo histórico,

... quando não somente os historiadores futuros, mas também os atores e testemunhas, os vivos mesmos, tornam-se conscientes de um intervalo no tempo totalmente determinado por coisas que não são mais e por coisas que não são ainda. Na História, esses intervalos mais de uma vez mostraram poder conter o momento da verdade. ${ }^{42}$

Em recente livro na forma de ensaio, publicado por ocasião dos 250 anos do grande terremoto que acometeu Lisboa em novembro de 1755, Rui Tavares disserta sobre as catástrofes e suas repercussões. Os incêndios de Roma em 64 d.C., o 11 de setembro de 2001, o tsunami de 2004, são comparados a eventos que, não obstante o número de vítimas equivalente ou superior, não tiveram o mesmo impacto mundial ante os contemporâneos e pósteros. Desse modo, o autor enfatiza a importância dos meios de comunicação, e o papel de certos desastres imprevisíveis como rupturas violentas da ordem histórica. ${ }^{43}$

Entre Roma e Lisboa, Tavares tece analogias com as imagens construídas dos grandes homens, de forma inversa: Nero destruiu Roma, Sebastião José reconstruiu Lisboa. Também destaca as leituras exageradas acerca das dimensões dos fatos. Para Lisboa chegou a ser inventado o número de setenta mil mortos, a cidade sendo varrida do mapa. Mas o fato é que o Grande Terramoto gerou enormes discussóes sobre as causas do sismo, a extensão dos danos, e as conseqüências do acontecimento. Objeções políticas, teológicas, filosóficas e literárias que ultrapassaram tempos e fronteiras. À maneira dos incêndios de Roma, o caos de Lisboa teria sido para muitos "o princípio do fim do Antigo Regime." ${ }^{44}$

O historiador ensaísta observa a relevância cultural destes acontecimentos, dada pelas suas circunstâncias, esclarecidas em dois eixos principais: a catástrofe num quadro cultural relacionado aos debates internos da sociedade, e a articulação do desastre aos media da época. No primeiro eixo explicativo, nota-se que o evento de 1755 proporcionou tanto obras de filósofos renomados, como simples "livros amuleto" que se penduravam no pescoço contra terremotos. Tratava-se em linhas gerais de um "pa- 
norama de pensamento", em que se encontravam o iluminismo e as relações entre religião e natureza. No segundo eixo, Tavares destaca as cartas, folhetos e livros impressos tão constitutivos do grande desastre de Lisboa, como a televisão e a internet para eventos mais contemporâneos. O "terremoto impresso" pode ter sido favorecido pelo fato de Lisboa ser um porto acessível às grandes rotas de navegação, famoso pela abundância real ou imaginada de mercadorias diversas e metais preciosos.

Com efeito, é possível observar o ano de 1755 não contaminado pela força do grande terramoto, quando os barcos saíam tranqüilamente da barra do Tejo, e a vida da corte era marcada pelo convívio com o soberano e sua família: mudança da residência régia para Belém, festas pelo aniversário do rei, do infante, a confirmação de novos beatos pelo papa. Em junho chegava a nova de que o marquês de Távora, após ser vice-rei, regressava da Índia, para retomar seu lugar na Corte como representante de grande família nobre portuguesa. O secretário de Negócios Estrangeiros Sebastião José de Carvalho e Melo chegara de Viena há alguns anos, como protegido da rainha-mãe D. Mariana de Áustria. D. Mariana tinha mais poder após a morte de $\mathrm{D}$. João $\mathrm{V}$, nos primeiros anos do reinado de $\mathrm{D}$. José I. Ela morreu em 1754, e no ano seguinte seu falecimento continuava a ser lembrado, bem como as exéquias do seu Fidelíssimo marido em 1750, celebradas em cidades do império português. Eventos fartamente descritos entre os folhetos coletados por Diogo Barbosa Machado.

Mas o grande terremoto se encontra praticamente ausente da coleção de opúsculos. Nenhum documento recortado o tem como objeto, as poucas menções em folhetos são por demais ligeiras. Após o ambiente descrito acima, o colecionador reuniu muitos relatos do atentado contra D. José I em 1758 - que implicava os Távoras - e sobre o nascimento do príncipe da Beira em 1761 - lembremos que o folheto mais recente na coleção é de 1770. Certo, não há nenhum volume entre os compilados pelo abade de Sever sobre as "catástrofes de Portugal", parafraseando título de uma obra acerca das agruras entre D. Afonso VI e D. Pedro, no século XVII. Todavia, não podemos menosprezar por essa ausência o impacto do evento na vida e na obra do colecionador. Ele deve ter sido enorme.

Pois ele foi imenso, em especial no mundo letrado. Em 1756, o jesuíta italiano residente em Lisboa Gabriel Malagrida publicava o pequeno 
livro intitulado Juizo da Verdadeira Causa do Terremoto. Como se sabe, nesta obra o padre escreveu que os lisboetas eram culpados pelo sismo, castigo divino a punir os maus católicos. A escrita de Malagrida baseava-se nos sermóes que pregou logo após o terremoto. $\mathrm{O}$ jesuíta era orador na corte de D. João V, e seu livro foi publicado com todas as licenças necessárias. Contudo, a história da pequena obra foi acompanhada do fortalecimento da política de Sebastião de Carvalho e Melo e suas articulações com a própria memória do desastre lisboeta. Em 1759, mesmo ano em que o secretário de Estado tornava-se conde de Oeiras, Malagrida - jesuíta e amigo dos Távoras - foi preso. Em 1761, foi queimado, última vítima mortal da Inquisição lusa. Em 1768, era criada a Real Mesa Censória; quatro anos depois o livro de Malagrida era condenado publicamente, com os piores adjetivos. Um dos censores do novo órgão, destinado a diminuir o poder do Santo Ofício, era o então bispo de Beja, Manuel do Cenáculo, artífice da reconstrução da Real Biblioteca, responsável pela negociação com o abade de Sever para o ganho da coleção Barbosa Machado. ${ }^{45}$

O impacto não foi menor entre os estrangeiros da "república das letras". O jovem alemão Immanuel Kant, por exemplo, forneceu uma explicação natural para os sismos, pela ação de gases subterrâneos à crosta terrestre. Contudo, mais famoso tornou-se o poema de François Voltaire sobre o desastre de Lisboa, contrariando a perspectiva do sábio Leibniz, resumida na frase "tudo vai bem". Da Suíça, Voltaire escreveu:

Acorrei, contemplai estas ruínas malfadadas, / Estes escombros, estes despojos, estas cinzas desgraçadas, / Estas mulheres, estes infantes uns nos outros amontoados / Estes membros dispersos sob estes mármores quebrados / Cem mil desafortunados que a terra devora / Os quais, sangrando, despedaçados, e palpitantes embora, / Enterrados com seus tetos terminam sem assistência / No horror dos tormentos sua lamentosa existência!

Aos que explicavam a origem do desastre pelas vias naturais ou pela fúria divina, Voltaire respondia com a própria imagem da Lisboa destruída: "Lisboa, que não é mais, teve ela mais vícios / Que Londres, que Paris, mergulhadas nas delícias? / Lisboa está arruinada, e dança-se em Paris." ${ }^{46}$

A sátira mordaz dirigida a Leibniz mereceu do ainda jovem JeanJacques Rousseau uma carta crítica a Voltaire que, no esplendor da sua maturidade intelectual, ainda escreveria a novela Cândido, ou o Otimismo, 
em 1758, com menções ao mesmo tema. Contudo, importa enfatizar o abalo causado pelo terremoto lisboeta no filósofo Voltaire, que oscilava entre duas explicações paradoxais - a natural e a divina -, sem optar por uma delas, preferindo a estupefação com o ocorrido. Esta brecha do tempo intelectual também pode ser percebida na história do livro do padre Malagrida. Rui Tavares disserta sobre as relações entre a construção da memória e a prática do poder, mediante o episódio da condenação da Real Mesa Censória. Como vimos, o livro com um juízo sobre o terremoto foi aceito, depois condenado, em meio à afirmação do pombalismo, construído em grande parte devido ao impacto de $1755 .^{47}$

Ao selecionar os folhetos que entravam em sua coleção, Barbosa Machado também atuava como censor, além de historiador. Lidava com a lembrança e também com o esquecimento. Entretanto, devemos ser atentos ao possível significado desta catástrofe, e da posterior reestruturação do espaço lisboeta sob a égide do conde Oeiras, depois marquês de Pombal, na escrita da história subjacente à coleção. ${ }^{48}$ Pensamos que as alterações se davam não apenas na quebra e na reorganização do espaço - Lisboa reconstruída -, mas também no tempo - a história de Portugal, refeita nesta brecha, recomposta mediante o arranjo com os folhetos. Essa reflexão é adensada, ao lembrarmos as circunstâncias que envolveram a estruturação da própria livraria do abade: a Academia Real de História, a coleção particular, a destruição da Real Biblioteca em 1755, a doação para integrar enfim o régio acervo.

Ao classificar e ordenar os folhetos em volumes, muito provavelmente após 1755, Diogo Barbosa Machado atuava nessas fissuras do tempo e do espaço. Juntava esses fragmentos de forma original, evitava sua destruição, tornando-os preciosos. Entre príncipes e varões valorosos dispostos por suas ações tematicamente, mas também entre o passar dos reinados, das batalhas e dos anos - lembremos da cronologia como segundo critério ordenador da coleção. De acordo com Hartog, a data discrimina, como seguro indício de uma escrita historiadora, atenta às discussões e ciosa das disjunçôes. A escolha de um ensaio como meio de abordagem do terremoto revela a não pretensão deste artigo em analisar o contexto pombalino, e mesmo as muitas inflexões acadêmicas possíveis acerca do evento de $1755 .{ }^{49}$ 
Mas, pelo que foi exposto, é possível dimensionar melhor o significado da história produzida pelo abade de Sever ao elaborar, ordenar e doar sua coleção particular, após o desastre que desorganizou a vida de sua cidade, capital do império português. À maneira do futuro Pombal, engenheiros e planos urbanos que reedificaram Lisboa, Diogo Barbosa Machado também reestruturava seu espaço-tempo, com base em elementos antigos justapostos a novos. Desse modo, a doação da coleção podia simbolizar também um novo tempo, um marco de impacto na restituição da biblioteca régia. Entretanto, essa "nova” história de Portugal e do império também pode, e deve, ser analisada como repertório de histórias antigas.

A busca da exata medida entre o velho e o novo, o antigo e o moderno, na obra do nosso Diogo, entre as diferentes concepções de história e as ordens do tempo, permanece difícil, senão impossível. Fiquemos com a mescla, as brechas e fissuras, e a subjetividade do conhecimento histórico, em todos os tempos - inclusive o nosso. E, em se tratando de um estudo sobre o tema, lembremos da figura daquele velho monge cego, o venerável Jorge de Burgos, na biblioteca em forma de labirinto com espelhos e ervas, artífice do livro envenenado no romance de Umberto Eco. Parece que o crítico literário, ao conceber a personagem, inspirou-se no homônimo Jorge Luis Borges, ex-diretor da Biblioteca Nacional na Argentina, autor do célebre conto La biblioteca de Babel. A biblioteca como livro, os livros como páginas. Por trás de qualquer ordem, a desordem. ${ }^{50}$

\section{Notas}

${ }^{1}$ Esta investigação se realiza desde 2003 na Biblioteca Nacional, sob coordenação de Rodrigo Bentes Monteiro e Pedro Cardim, conta com as pesquisas de David Felismino e de Ana Paula Sampaio Caldeira, e com o trabalho dos estagiários Pedro Fonseca de Araujo, Gustavo Kelly de Almeida, Jerônimo Duque Estrada de Barros e Jorge Miranda Leite. Agradecemos a Valeria Gauz e Íris Kantor as sugestóes para este artigo.

${ }^{2}$ Diogo Barbosa Machado descreveu este conjunto documental como uma "colecção singular, e de suma estimação que consta de sucessos pertencentes à História de Portugal formada de vários livros de prosa e verso da dita história e reduzida a folha em volumes...” Não usou, portanto, os termos folhetos ou opúsculos. No Vocabulário ... de Bluteau, opúsculo significa "obra, livro, tratado pequeno sobre qualquer matéria ...", e não há menção a folheto. Os dois termos são empregados como sinônimos para referência aos documentos da coleção pelos bibliotecários Ramiz Galvão e Rosemarie Horch, como veremos adiante. MACHADO, Diogo Barbosa. Cathalogo dos Livros da Livraria 
Diogo Barbosa Machado distribuidos por matérias e escrito por sua própria mão. Rio de Janeiro: Biblioteca Nacional, p.33. BLUTEAU, Raphael. Vocabulário Português e Latino ... Coimbra: Colégio das Artes da Cia de Jesus, 1712, p.94.

${ }^{3}$ KRIEGEL, Blandine. L'Histoire à l'Age Classique. La défaite de l'erudition. Paris: PUF, 1988, v.2, p.165.

${ }^{4}$ KANTOR, Íris. Esquecidos e Renascidos. Historiografia acadêmica luso-americana (17241759). São Paulo: Hucitec, 2004, p.19.

${ }^{5}$ Sobre este assunto ver BRIGOLA, João Carlos Pires. Colecções, Gabinetes e Museus em Portugal no Século XVIII. Coimbra: Fundação Calouste Gulbenkian, 2003.

${ }^{6}$ ALVAREZ, Fernando Bouza. Del Escribano a la Biblioteca: La civilización escrita europea en la alta edad moderna (siglos XV-XVII). Madrid: Sintesis, 1997; Corre Manuscrito: Una historia cultural del siglo de oro. Madrid: Marcial Pons, 2001.

${ }^{7}$ GINZBURG, Carlo. Olhos de Madeira. Nove reflexôes sobre a distância. São Paulo: Companhia das Letras, 2001, p.85-103.

${ }^{8}$ POMIAN, Krzysztof. Colecção, in: ROMANO, Ruggiero (dir.). Enciclopédia Einaudi. Memória - História. Lisboa: Imprensa Nacional - Casa da Moeda, 1984, v.1, p.51-86.

${ }^{9}$ LUGLI, Adalgisa. Naturalia et Mirabilia. Les cabinets de curiosités en Europe. Paris: Adam Biro, 1998; SCHNAPPER, Antoine. Le Géant, la Licorne et la Tulipe. Paris: Flammarion, 1988 e BRIGOLA, op. cit.

${ }^{10}$ LUGLI, op. cit.; KRIEGEL, op. cit., p.165.

${ }^{11}$ BRIGOLA, op. cit., p.507-513.

12 POMIAN, op. cit.; KRIEGEL, L'Histoire à l'Age Classique. Les academies de l'histoire. Paris: PUF, 1988, v.3, p.35.

${ }^{13}$ MOTA, Isabel Ferreira da. A Academia Real da História. Os intelectuais, o poder cultural e o poder monárquico no século XVIII. Coimbra: Minerva, 2003. p.227-229.

${ }^{14}$ A formação oratoriana deve ter contribuído para o interesse colecionista de Barbosa Machado, uma vez que esta congregação era conhecida por seu trabalho de edição, revisão e publicação de documentos. A respeito do envolvimento deste grupo e de outras ordens religiosas com o saber histórico ao longo dos séculos XVII e XVIII, ver a coleção de KRIEGEL, op. cit., e BOURDÉ, Guy. As Escolas Históricas. Lisboa: Europa-América, 1983. ${ }^{15}$ MOTA, op. cit.

${ }^{16}$ SYLVA, Manoel Telles da. Historia da Academia Real da Historia Portugueza. Lisboa: Officina de Joseph Antonio da Sylva, 1727, p.316-318. Sobre a nobreza em Portugal no século XVIII, MONTEIRO, Nuno Gonçalo Freitas. O Crepúsculo dos Grandes. A casa e o patrimônio da aristocracia em Portugal (1750-1832). Lisboa: Imprensa Nacional - Casa da Moeda, 2003.

${ }_{17}$ SERRA, Francisco José da. Oração Fúnebre nas Exequias do reverendo senhor Diogo Barbosa Machado, abbade reservatório da paroquial igreja de Santo Adriāo de Cever. Lisboa: Regia Officina Typografica, 1773. MOTA, op. cit. 
${ }^{18} \mathrm{MACHADO}$, op. cit. Cf. também HORCH, Rosemarie Erika. (org.). Catálogo dos folhetos da coleção Barbosa Machado. Anais da Biblioteca Nacional. Rio de Janeiro: Biblioteca Nacional, 1972, v.92, p.30-32.

${ }^{19}$ KRIEGEL, op. cit., v.2, p. 205.

${ }^{20}$ A este respeito, cf. MONTEIRO, Rodrigo Bentes. Recortes de memória: reis e príncipes na coleção Barbosa Machado, in: SOIHET, Rachel; BICALHO, Maria Fernanda \& GOUVÊA, Maria de Fátima Silva (org.). Culturas Politicas. Ensaios de história cultural, história politica e ensino de história. Rio de Janeiro: Mauad, 2005, p.127-154; e Reis, príncipes e varões insignes na coleção Barbosa Machado. Anais de História de Além-Mar. Lisboa: Centro de História de Além-Mar, 2005, p.215-251.

${ }^{21}$ Sobre a função representativa dos reis, cf. KANTOROWICZ, Ernst. Os Dois Corpos do Rei. Um estudo de teologia politica medieval. São Paulo: Companhia das Letras, 1998; BOUREAU, Alain, Le roi, in: NORA, Pierre (org.). Les Lieux de Mémoire. Paris: Gallimard, 1997, v.3, p.4521-4544; MONTEIRO, Rodrigo. O Rei no Espelho. A monarquia portuguesa e a colonização da América 1640-1720. São Paulo: Hucitec, 2002.

22 Para citar apenas referências recentes sobre os feitos militares e sua divulgação, cf. BARATA, Manuel Themudo \& TEIXEIRA, Nuno Severiano (dir.). Nova História Militar de Portugal. Lisboa: Círculo de Leitores, 2004, v.2; BEBIANO, Rui. A Pena de Marte. Escrita da guerra em Portugal e na Europa (sécs. XVI-XVIII). Coimbra: Minerva, 2000.

${ }^{23}$ Acerca da aristocracia em Portugal, cf. MONTEIRO, Nuno, op. cit. Sobre as reuniōes de cortes, CARDIM, Pedro. Cortes e Cultura Politica no Portugal do Antigo Regime. Lisboa: Cosmos, 1998. Sobre a interação entre os campos político e religioso nas sociedades do Antigo Regime, KANTOROWICZ, op. cit., BLOCH, Marc. Os Reis Taumaturgos. $O$ caráter sobrenatural do poder régio França e Inglaterra. São Paulo: Companhia das Letras, 1993; CARDIM, Religião e ordem social. Em torno dos fundamentos católicos do sistema político do Antigo Regime. Revista de História das Idéias. Coimbra: Instituto de História e Teoria das Idéias - Faculdade de Letras da Universidade de Coimbra, 2001, v.22, p.133-174; PAIVA, José Pedro. A Igreja e o poder, in: MARQUES, João Francisco \& GOUVEIA, António Camões (org.). História Religiosa de Portugal. Lisboa: Círculo de Leitores, 2000, v.2, p.135-183.

${ }^{24}$ Sobre o estudo dos sermões na Restauração, MARQUES. A Parenética Portuguesa e a Restauração 1640-1668. Porto: Instituto Nacional de Investigação Científica, 1989, 2 v; Para a inquisição em suas relações políticas BETHENCOURT, Francisco. História das Inquisiçôes. Portugal, Espanha e Itália Séculos XV-XIX. São Paulo: Companhia das Letras, 2000.

25 Parece que Diogo Barbosa Machado tinha desavenças com a Companhia de Jesus. Atribui-se a ele a Carta Exhortatoria aos Padres da Companhia de Jesus da Província de Portugal, publicada sem indicações, obra em defesa dos oratorianos contra os jesuítas na guerra doutrinal e literária entre as duas congregaçóes. COSTA, Manuel Alberto Nunes. Diogo Barbosa Machado e a bibliografia portuguesa. Anais da Academia Portuguesa de História, Lisboa: s. ed., 1986, p.291-340.

${ }^{26}$ Devido à peculiaridade desta coleção, e ao fato de acervos congêneres serem destruídos no terremoto de 1755 , é difícil comparar esta ordem a outros conjuntos semelhantes no 
mesmo contexto. Ronald Raminelli empenhou-se em desvendar a taxionomia empregada pelo naturalista Alexandre Rodrigues Ferreira, mas a diversidade das fontes impede uma aproximação ao conjunto compilado pelo abade. Sabe-se que a livraria do acadêmico era composta por aproximadamente 4.300 obras em 5.764 volumes, divididos em 34 classes. O número de livros por classificação varia bastante. No entanto, interessa destacar que à história, eclesiástica ou profana, segundo a própria classificação de Barbosa Machado, são reservadas 1.169 obras, $27 \%$ da livraria. Incluindo livros de vidas de personagens, chega-se a 34\%. Ana Cristina Araújo pesquisa bibliotecas portuguesas do Setecentos, centrando-se na de José da Silva Pais, sargento-mor que - acompanhando Barbosa Machado - também ascendeu socialmente. Esta biblioteca era composta por 437 volumes, na qual Araújo destaca 252 dedicados à história e vidas de príncipes. Embora discrepantes, as livrarias demonstram o interesse de letrados e do mercado livreiro da época pela história. RAMINELLI, Ronald. Do conhecimento físico e moral dos povos: iconografia e taxionomia na Viagem Filosófica de Alexandre Rodrigues Ferreira. História, Ciências, Saúde - Manguinhos, 2001, v. VIII (suplemento), p.969-92; ARAÚJO, Ana Cristina. Livros de uma vida. Critérios e modalidades de constituição de uma livraria particular no século XVIII. Revista de História das Idéias. Coimbra: Instituto de História e Teoria das Idéias - Faculdade de Letras da Universidade de Coimbra, 1999, v.20, p.149-185.

${ }^{27}$ LE GOFF, Jacques. Memória, in: ROMANO, op. cit., p.11-50.

${ }^{28}$ Em análise clássica, Reinhart Koselleck mostrou como na Alemanha nos anos 17601780, a formação do moderno conceito de história aos poucos esvaziou a substância dessa concepção de história que conjugava exemplo e repetição. A História passou a entender-se como processo, concebendo-se como história em si, abandonando o exemplo e ligando-se ao acontecimento. Essas reflexões da escola histórica alemã, formuladas antes, acharam uma "prova” na Revolução francesa, vivida por muitos como uma aceleração do tempo, fazendo uma brutal distensão entre o campo de experiências e o horizonte de expectativas. KOSELLECK, Reinhart. Futuro Pasado. Para una semántica de los tiempos históricos. Barcelona: Paidos, 1993, p.41-66 e historia / Historia. Madrid: Trotta, 2004.

${ }^{29}$ SILVA, op. cit., p.85.

${ }^{30}$ KRIEGEL, op. cit., v.2., p.18.

${ }^{31}$ BLUTEAU, op. cit., p.39-40.

32 Para Koselleck, o tempo histórico é produzido pela distância entre experiências e expectativas, engendrado pela tensão entre elas. A estrutura temporal dos tempos modernos - a partir do final do século XVIII -, marcada pela abertura ao futuro e ao progresso, é caracterizada pela assimetria entre experiências e expectativas. Este desequilíbrio cresceria sob efeito da aceleração. A fórmula "menor a experiência, maior a expectativa" resume esta evolução. Já em 1975 Koselleck se interrogava sobre o que podia ser um fim ou uma saída para esses tempos. Começa a definir-se então a contribuição de François Hartog, ao dissertar sobre o presentismo. KOSELLECK, Futuro Pasado ..., op. cit., p.333-357. Cf. também o seu estudo seminal Crítica e Crise. Uma contribuição à patogênese do mundo 
burguês. Rio de Janeiro: Eduerj / Contraponto, 1999, e HARTOG, François. Regimes d'Historicité. Présentisme et expériences du temps. Paris: Seuil, 2003, p.28.

${ }^{33}$ GALVÃO, Benjamin Franklin Ramiz. Diogo Barbosa Machado. Anais da Biblioteca Nacional. Rio de Janeiro: Biblioteca Nacional, 1876-1877, v.1, p.1-43, reproduzido em 1972, v.92, p.11-45, e Diogo Barbosa Machado. Catálogo de suas coleções, Anais da Biblioteca Nacional. Rio de Janeiro: Biblioteca Nacional, 1876-1877, v.2, p.128-191; 1877-1878, v.3, p.162-181 e 279-311; e 1880-1881, v.8, p.222-431. BRUM, José Zepherino de M. (org.), Catálogo dos retratos colligidos por Diogo Barbosa Machado. Anais da Biblioteca Nacional. Rio de Janeiro: Biblioteca Nacional, 1893 / 1896 / 1898 / 1904, vs.16, 18, 20 e 26. Sobre a restauração dos retratos no século XIX e a gestão de Ramiz Galvão na Biblioteca Nacional, cf. MONTEIRO, Rodrigo, Recortes de memória ..., op. cit. ${ }^{34} \mathrm{HORCH}$, Entrevista a Rodrigo Bentes Monteiro. São Paulo: Instituto de Estudos Brasileiros - USP, 20/10/2005. A polissemia entre restaurar, restituir, refazer, é bastante antiga. Vespasiano empreendeu a restitutio do Capitólio, devastado por um incêndio: ele o restaurou, portanto. Mas ao mesmo tempo restituiu três mil tabletes de bronze, fundidos no mesmo incêndio. Como restaurá-los, se desapareceram? Assim, restitutio não significava restauração, mas sim refazimento, nova fabricação. HARTOG, op. cit., p.173. ${ }^{35}$ A ordenação pressupõe pesquisa, nos séculos XX, XIX ou XVIII. Embora os membros da Academia Real colecionassem individualmente documentos e objetos, a instituição também se interessava em ter seu arquivo e seu museu, para escrever sua própria história. Dessa forma, os eruditos reuniam e colecionavam o que fosse necessário. Os acadêmicos elaboravam memórias para mostrar pontos duvidosos de um período, destacando personagens e feitos por meio de documentos úteis à história lusa, como fez Barbosa Machado para os reinados de D. Sebastião e dos Habsburgos: compilou decretos, cartas e outros documentos, descrevendo também açōes de varôes insignes cuja lealdade devia ser lembrada. Essa pesquisa também foi feita pelo abade ao montar sua Bibliotheca Lusitana... Neste catálogo de escritores portugueses e suas produções - dispostos em ordem alfabética por seus prenomes -, Barbosa Machado consultou trabalhos semelhantes e pediu ajuda a outros eruditos, solicitando-lhes informaçôes de autores portugueses. Desse modo, os quatro tomos da Bibliotheca Lusitana... e a coleção de folhetos constituem elogios à história lusa mediante o trabalho de Barbosa Machado de coletar e ordenar. MACHADO, Diogo Barbosa. Bibliotheca Lusitana, Historica, Critica e Chronologica na qual comprehende a noticia dos auctores portuguezes, e das obras que compuzerão desde o tempo da promulgação da Ley da Graça até o tempo prezente ..., Lisboa Occidental: Officina de Antonio Isidoro da Fonseca, 1747-1759, 4 v.

${ }^{36}$ CARVALHO, Gilberto Vilar de. Biografia da Biblioteca Nacional (1807 a 1990). Rio de Janeiro: Irradiação Cultural, 1994, p.96-112.

${ }^{37}$ CASTRO, César Augusto. História da Biblioteconomia Brasileira. Brasília: Thesaurus, 2000.

${ }^{38} \mathrm{HORCH}$ (org), Catálogo dos folhetos da coleção Barbosa Machado, op. cit., 1974-1988, v.92, 8 v. Para detalhes da conjuntura da Biblioteca Nacional nos anos 1970, cf. MONTE-MÓR, Jannice. A Biblioteca Nacional em 1972, in idem, 1972, v.92, p.255-273. 
39 "Raça e história" foi encomendado e publicado pela Unesco em 1952. Cf. SAHLINS, Marshall. Ilhas de História. Rio de Janeiro: Zahar, 1990.

${ }^{40}$ Para as seguintes reflexôes, HARTOG, op. cit. O artigo assemelha-se mais a esta abordagem, do que à elaboração de "cronosofias" - como diferentes filosofias do tempo, proposta por POMIAN, L'Ordre du Temps. Paris: Gallimard, 1984.

${ }^{41}$ Priorizando o caso francês, Hartog trabalha a mudança de regimes de historicidade no século XX: na escola dos Annales, os historiadores esquivam-se do nacional, preferindo o econômico-social, com temporalidades diferentes da linha de eventos políticos. A história contribui para o saber sobre a sociedade em si, e a legitimação pelo passado cede lugar à legitimação para o futuro, evidenciando o presentismo. Nos anos oitenta, Les Lieux de Mémoire de Pierre Nora reforça a idéia de memória, um diagnóstico sobre o presente da França: Nora não invoca o tempo progressista, mas não sai do presente, negando a ruptura entre este e o passado. Rompe-se assim com as histórias memórias nacionais escritas do ponto de vista do futuro, pois a nova epistemologia reivindica a centralidade do presente. HARTOG, op. cit., p.113-206.

${ }^{42}$ ARENDT, Hannah. Entre o Passado e o Futuro. São Paulo: Perspectiva, 1988, p.35-36. Nesse sentido Hartog entende a trajetória do escritor francês Chateaubriand (1768-1848), entre o antigo e o novo regime de historicidade. Sua escrita partia dessa mudança de regimes, ao voltar-se para a brecha do tempo aberta por 1789. Retomando Arendt, ele elegeu por lugar a quebra do tempo. HARTOG, op. cit., p.12-17 e p.77-107.

${ }^{43}$ Para as seguintes informaçóes, TAVARES, Rui. O Pequeno Livro do Grande Terramoto. Ensaio sobre 1755. Lisboa: Tinta da China, 2005, p.18-65.

${ }^{44}$ Idem, p. 18.

${ }^{45}$ Idem, p.135-149. Brigola informa-nos sobre a devastação dos palácios e das respectivas coleções na Lisboa do terremoto, o que parece valorizar a coleção Barbosa Machado. BRIGOLA, op. cit., p.52-53.

46 TAVARES, op. cit., p.151-165. Voltaire apud idem, p.157.

47 "A censura, tal como a propaganda, desempenharia assim, no território da memória, o equivalente às funçōes que desempenham as fortalezas, os baluartes e os exércitos no território real, geográfico, dos reinos e dos impérios." Idem, p.146.

${ }^{48}$ CERTEAU, Michel. A Escrita da História. Rio de Janeiro: Forense Universitária, 2002. Cf. também GUIMARÃES, Manoel Luís Salgado. Reinventando a Tradição: sobre antiquariado e escrita da história. Humanas, Porto Alegre: 2000, v. 23, n. 1/2, p.111-143. A acepção de Pombal como protagonista desta brecha do tempo é sugerida no título do conhecido livro de MAXWELL, Kenneth. Marquês de Pombal. Paradoxo do Iluminismo. Rio de Janeiro: Paz e Terra, 1996.

${ }^{49}$ Em 2005, vários debates foram promovidos em Portugal sobre o assunto, dos quais certamente resultarão publicações. A título de exemplo, o colóquio internacional $O$ Terramoto de 1755. Impactos históricos. Lisboa: Departamento de História do Instituto 
Superior de Ciências do Trabalho e da Empresa / Instituto de Ciências Sociais da Universidade de Lisboa, 2005.

${ }^{50}$ ECO, Umberto. Il Nome della Rosa. In appendice postille a "Il nome della rosa". Milano: Tascabili Bompiani, 2005, p.515; BORGES, Jorge Luis. La biblioteca de Babel, in: Ficciones. Buenos Aires: Emecé, 2004, p.105-122.

\section{Fontes}

BLUTEAU, Raphael. Vocabulário Português e Latino. Coimbra: Colégio das Artes da Cia de Jesus, 1712.

BRUM, José Zepherino de M. (org.). Catálogo dos retratos colligidos por Diogo Barbosa Machado. Anais da Biblioteca Nacional. Rio de Janeiro: Biblioteca Nacional, 1893 / 1896 / 1898 / 1904, vs.16, 18, 20 e 26.

GALVÃO, Benjamin Franklin Ramiz. Diogo Barbosa Machado. Catálogo de suas coleçōes. Anais da Biblioteca Nacional. Rio de Janeiro: Biblioteca Nacional, 1876-1877, v.2, p.128-191; 1877-1878, v.3, p.162-181 e 279-311; e 1880-1881, v.8, p.222-431.

- Diogo Barbosa Machado. Anais da Biblioteca Nacional. Rio de Janeiro: Biblioteca Nacional, 1876-1877, v.1, p.1-43.

HORCH, Rosemarie Erika (org.). Catálogo dos folhetos da coleção Barbosa $M a-$ chado. In: Anais da Biblioteca Nacional. Rio de Janeiro: Biblioteca Nacional, 1972, v.92, $8 \mathrm{t}$.

- Entrevista a Rodrigo Bentes Monteiro. São Paulo: Instituto de Estudos Brasileiros - USP, 20/10/2005.

MACHADO, Diogo Barbosa. Bibliotheca Lusitana, Historica, Critica e Chronologica na qual comprehende a noticia dos auctores portuguezes, e das obras que compuzerão defde o tempo da promulgaçao da Ley da Graça até o tempo prezente. Lisboa Occidental: Officina de Antonio Isidoro da Fonseca, 1747-1759, 4 v. - Cathalogo dos Livros da Livraria Diogo Barbosa Machado distribuidos por matérias e escrito por sua própria mão. Rio de Janeiro: Biblioteca Nacional. - Coleção de opúsculos. Rio de Janeiro: Biblioteca Nacional, 145 v. . Memórias para a História de Portugal, que comprehendem o governo del Rey D. Sebastiāo. Lisboa: Officina de Joseph Antonio da Sylva, 1736-1751. SYLVA, Manoel Telles da. Historia da Academia Real da Historia Portugueza. Lisboa: Officina de Joseph Antonio da Sylva, 1727. 


\section{Referências bibliograficas}

ALVAREZ, Fernando Bouza. Corre Manuscrito: Una historia cultural del siglo de oro. Madrid: Marcial Pons, 2001.

- Del Escribano a la Biblioteca: La civilización escrita europea en la alta edad moderna (siglos XV-XVII). Madrid: Sintesis, 1997.

ARENDT, Hannah. Entre o Passado e o Futuro. São Paulo: Perspectiva, 1988.

ARAÚJO, Ana Cristina. Livros de uma vida. Critérios e modalidades de constituição de uma livraria particular no século XVIII. Revista de História das Idéias. Coimbra: Instituto de História e Teoria das Idéias - Faculdade de Letras da Universidade de Coimbra, 1999, v.20, p.149-185.

BARATA, Manuel Themudo \& TEIXEIRA, Nuno Severiano (dir.). Nova História Militar de Portugal. Lisboa: Círculo de Leitores, 2004, v.2.

BARATIN, Marc \& JACOB, Christian (org.). O Poder das Bibliotecas. A memória dos livros no Ocidente. Rio de Janeiro: UFRJ, 2000.

BEBIANO, Rui. A Pena de Marte. Escrita da guerra em Portugal e na Europa (sécs. XVI-XVIII). Coimbra: Minerva, 2000.

BETHENCOURT, Francisco. História das Inquisiçōes. Portugal, Espanha e Itália séculos XV-XIX. São Paulo: Companhia das Letras, 2000.

BLOCH, Marc. Os Reis Taumaturgos. O caráter sobrenatural do poder régio França e Inglaterra. São Paulo: Companhia das Letras, 1993.

BORGES, Jorge Luis. Ficciones. Buenos Aires: Emecé, 2004.

BOURDÉ, Guy. As Escolas Históricas. Lisboa: Europa-América, 1983.

BRIGOLA, João Carlos Pires. Colecçôes, Gabinetes e Museus em Portugal no Século XVIII. Coimbra: Fundação Calouste Gulbenkian, 2003.

CARDIM, Pedro. Cortes e Cultura Politica no Portugal do Antigo Regime. Lisboa: Cosmos, 1998.

Religião e ordem social. Em torno dos fundamentos católicos do sistema político do Antigo Regime. Revista de História das Idéias. Coimbra: Instituto de História e Teoria das Idéias - Faculdade de Letras da Universidade de Coimbra, 2001, v.22, p.133-174.

CARVALHO, Gilberto Vilar de. Biografia da Biblioteca Nacional (1807 a 1990). Rio de Janeiro: Irradiação Cultural, 1994.

CASTRO, César Augusto. História da Biblioteconomia Brasileira. Brasília: Thesaurus, 2000. 
CERTEAU, Michel. A Escrita da História. Rio de Janeiro: Forense Universitária, 2002.

COSTA, Manuel Alberto Nunes. Diogo Barbosa Machado e a bibliografia portuguesa. Anais da Academia Portuguesa de História. Lisboa: s. ed., 1986, p.291-340. CUNHA, Norberto. Elites e Acadêmicos na Cultura Portuguesa Setecentista. Lisboa: Imprensa Nacional-Casa da Moeda, 2000.

ECO, Umberto. Il Nome della Rosa. In appendice postille a "Il nome della rosa". Milano: Tascabili Bompiani, 2005.

GINZBURG, Carlo. Olhos de Madeira. Nove reflexôes sobre a distância. São Paulo: Companhia das Letras, 2001.

GRAFTON, Anthony. As Origens Trágicas da Erudição. Pequeno tratado sobre a nota de rodapé. Campinas: Papirus, 1998.

GUIMARÃES, Manoel Luiz Salgado. Reinventando a Tradição: sobre antiquariado e escrita da história. Humanas. Porto Alegre: 2000, v. 23, n.1/2, p.111-143.

HARTOG, François. Regimes d'Historicité. Presentisme et experiences du temps. Paris: Seuil, 2003.

HESPANHA, Antonio Manuel (org.). História de Portugal. O Antigo Regime. Lisboa: Círculo de leitores, 1993, v.4.

KANTOR, Íris. Esquecidos e Renascidos. Historiografia acadêmica luso-americana (1724-1759). São Paulo: Hucitec, 2004.

KANTOROWICZ, Ernst. Os Dois Corpos do Rei. Um estudo de teologia politica medieval. São Paulo: Companhia das Letras, 1998.

KOSELLECK, Reinhart. Crítica e Crise. Uma contribuição à patogênese do mundo burguês. Rio de Janeiro: Eduerj/Contraponto, 1999.

Paidos, 1993.

Futuro Pasado. Para una semántica de los tiempos históricos. Barcelona: historia/Historia. Madrid: Trotta, 2004.

KRIEGEL, Blandine Barret. L'Histoire à L'Age Classique. Paris: PUF, 1988, 4 v. LUGLI, Adalgisa. Naturalia et Mirabilia. Les cabinets de curiosités en Europe. Paris: Adam Biro, 1998.

MARQUES, João Francisco. A Parenética Portuguesa e a Restauração 1640-1668. Porto: Instituto Nacional de Investigação Científica, 1989, 2 v.

. \& GOUVEIA, António Camões (org.). História Religiosa de Portugal. Lisboa: Círculo de Leitores, 2000, v.2.

MAXWELL, Kenneth. Marquês de Pombal. Paradoxo do Iluminismo. Rio de Janeiro: Paz e Terra, 1996. 
MONTEIRO, Nuno Gonçalo Freitas. O Crepuisculo dos Grandes. A casa e o patrimônio da aristocracia em Portugal (1750-1832). Lisboa: Imprensa Nacional Casa da Moeda, 2003.

MONTEIRO, Rodrigo Bentes. O Rei no Espelho. A monarquia portuguesa e a colonização da América 1640-1720. São Paulo: Hucitec, 2002.

. Recortes de memória: reis e príncipes na coleção Barbosa Machado. In: SOIHET, Rachel; BICALHO, Maria Fernanda \& GOUVÊA, Maria de Fátima Silva (org.). Culturas Politicas. Ensaios de história cultural, história política e ensino de história. Rio de Janeiro: Mauad, 2005, p.127-154.

Reis, príncipes e varōes insignes na coleção Barbosa Machado. Anais de História de Além-Mar. Lisboa: Centro de História de Além-Mar, 2005, no prelo.

MOTA, Isabel Ferreira da. A Academia Real da História. Os intelectuais, o poder cultural e o poder monárquico no século XVIII. Coimbra: Minerva, 2003.

NORA, Pierre (org.). Les Lieux de Mémoire. Paris: Gallimard, 1997, 3 v.

POMIAN, Krzysztof. Collectionneurs, Amateurs et Curieux: Paris-Venise, XVIeXVIIe siècle. Paris: Gallimard, 1987.

. Des Saintes Reliques à l'art Moderne: Venise-Chicago, XIIIe-XXe siècle.

Paris: Gallimard, 2003. L'Ordre du Temps. Paris: Gallimard, 1984.

RAMINELLI, Ronald. Do conhecimento físico e moral dos povos: iconografia e taxionomia na Viagem Filosófica de Alexandre Rodrigues Ferreira. História, Ciências, Saúde - Manguinhos, 2001, v. VIII (suplemento), pp.969-92. http:// www.scielo.br

ROMANO, Ruggiero (dir.). Enciclopédia Einaudi. Memória - História. Lisboa: Imprensa Nacional - Casa da Moeda, 1984, v.1.

SAHLINS, Marshall. Ilhas de História. Rio de Janeiro: Zahar, 1990.

SCHNAPPER, Antoine. Le Géant, la Licorne et la Tulipe. Paris: Flammarion, 1988.

TAVARES, Rui. O Pequeno Livro do Grande Terramoto. Ensaio sobre 1755. Lisboa: Tinta da China, 2005. 


\section{RESUMO}

Neste artigo, os autores estudam a grande coleção de opúsculos montada no século XVIII pelo bibliófilo português Diogo Barbosa Machado, que integra atualmente o acervo da Biblioteca Nacional, no Rio de Janeiro. Destaca-se inicialmente a importância da escrita na Época Moderna e a circulação de folhetos impressos como elementos de poder. Em seguida, discute-se a coleção como agrupamento de peças preciosas, $e$ a trajetória de ascensão social de seu artífice. O ponto central do artigo é a taxionomia empreendida pelo colecionador, relacionada também aos vários tempos percorridos pela coleção. Formula-se assim a hipótese da brecha do tempo em que vivia Barbosa Machado.

Palavras-chave: Biblioteca Nacional, coleção Barbosa Machado, folhetos, monarquia portuguesa.

\section{ABSTRACT}

In this article, the authors study Diogo Barbosa Machado's great collection of pamphlets gathered during the eighteenth-century and housed at the Biblioteca Nacional, Brazil. At first, they highlight the importance of the written texts during the Modern Age and the circulation of printed documents as tools of power. Then they discuss the collection itself as an amalgamation of valuable pieces, as well as the way the Machado used collecting as a means to gain social prestige. The central point of the article is the discussion of systematic, or division into categories (taxonomy) that the Portuguese collector decided upon to organize the volumes as he assembled them, which is also related to the various times along with the collection was put together. In such a manner, the authors formulate the hypothesis of break in time in which Barbosa Machado lived.

Keywords: National Library of Brazil, Barbosa Machado's collection, pamphlets, Portuguese Monarchy.

(recebido em janeiro de 2006 e aprovado em setembro do mesmo ano) 